\title{
Time-Lapse Gravity Monitoring of Groundwater of the Sinai Peninsula
}

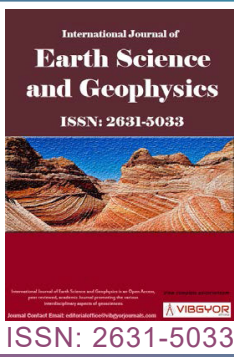

\section{Ahmed Mohamed}

\author{
Geology Department, Faculty of Science, Assiut University, Assiut, Egypt
}

\begin{abstract}
The Middle East is suffering from water scarcity in the arid/semiarid settings. The recent advance of technologies in the geophysical fields made groundwater monitoring possible from space. Time-variable gravity data and climatic model are utilized to monitor mass variations caused by groundwater changes over the Sinai Peninsula during the period 04/2002-07/2016. Results are: (1) Sinai Peninsula is receiving low average annual precipitation (AAP) rate, varying from $22.3 \mathrm{~mm} / \mathrm{yr}$ to $68.5 \mathrm{~mm} / \mathrm{yr}$; (2) The average annual Terrestrial Water Storage variations ( $\triangle T$ TWS) were estimated at $-3.92 \pm 0.23 \mathrm{~mm} / \mathrm{yr}$; (3) The average yearly non-groundwater components were estimated at $-1.35 \pm 0.032 \mathrm{~mm} / \mathrm{yr}$; (4) The average annual groundwater storage variations ( $\triangle \mathrm{GWS}$ ) were estimated at $-2.57 \pm 0.22 \mathrm{~mm} / \mathrm{yr}$. The depletion in the mass variations over Sinai seems to be caused by the natural discharge, low rainfall rates, and the surface runoff from the land toward the water bodies. The integrated approach is informative and a replicable study for the areas of poor information.
\end{abstract}

\section{Keywords}

Time-variable gravity, GLDAS, Terrestrial water storage, Depletion rate, Sinai Peninsula

\begin{abstract}
Abbreviations
AAP: Average Annual Precipitation; CLM: Community Land Model; CSR-M: Mascon Solutions of CSR center; DLR: German Aerospace Center; GFZ: German Research Centre for Geosciences; GLDAS: Global Land Data Assimilation System; GRACE: Gravity Recovery and Climate Experiment; GWS: Groundwater Storage; JPL: Jet Propulsion Laboratory; LSM: Land Surface Model; MAMSL: M-Above Mean Sea Level; MASCON: Mass Concentration; MON: Monthly; NASA: National Aeronautics and Space Administration; SMS: Soil Moisture Storage; TRMM: Tropical Rainfall Measuring Mission; TWS: Terrestrial Water Storage; UT-CSR: University of Texas Center for Space Research; VIC: Variable Infiltration Capacity
\end{abstract}

\section{Introduction}

Terrestrial water storage (TWS) plays an important role in the climate system of the Earth [1]. Given the importance of the TWS, there are many paucities in the data on the regional and global scale [2]. With the advances in satellite gravimetric methods,
TWS observations have become directly available over a vast area. The launch of the GRACE as a joint NASA-DLR mission in 2002 to detect variations in the Earth that are used to monitor the TWS changes. GRACE cannot distinguish between the different partitions of TWS. Therefore, the outputs of the

*Corresponding author: Ahmed Mohamed, Geology Department, Faculty of Science, Assiut University, Assiut, 71516, Egypt, Tel: 0100-839-0135

Accepted: December 14, 2020; Published: December 16, 2020

Copyright: (c) 2020 Mohamed A. This is an open-access article distributed under the terms of the Creative Commons Attribution License, which permits unrestricted use, distribution, and reproduction in any medium, provided the original author and source are credited.

Mohamed. Int J Earth Sci Geophys 2020, 6:040

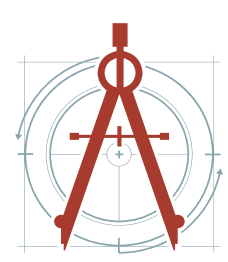


land surface model are integrated with GRACE data to partition the TWS into its different components.

GRACE data have been widely used in the analysis of the characteristics of TWS seasonality [3]. GRACE data can be used for identifying the extreme climatic impacts like floods and drought $[4,5]$. Some hydrological information can be combined with GRACE data to understand variables in the hydrological cycle, and hydrological investiga- tions, including e.g., (a) Water balance and storage variabilities [6-9] and (b) Aquifer behavior (e.g., [10-18]). The advantage of GRACE over other traditional measurements is its ability to measure the total water storage from the surface down to the deepest aquifer.

The Sinai Peninsula has an area of $61,000 \mathrm{~km}^{2}$ and represents the Asiatic part of Egypt. Gulf of Suez and the Suez Canal are geographically sepa-

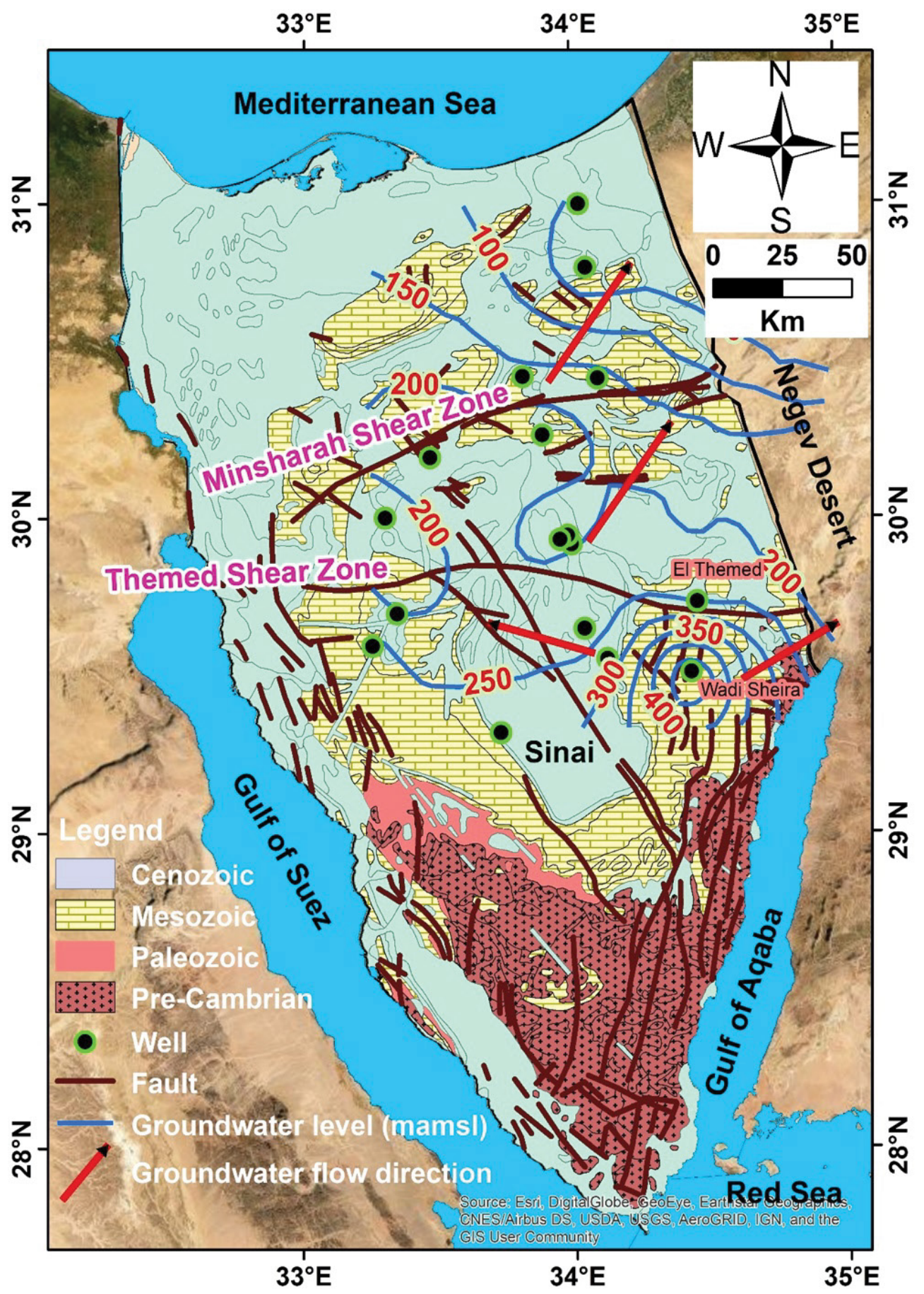

Figure 1: Showing the geology of the study area. Also shown are the locations of wells, faults, and shear zones. Also shown are the groundwater level (MAMSL) and groundwater flow direction. 
rating the Sinai Peninsula from Egypt. It is bounded to the east, and north by the Gulf of Aqaba, and the Mediterranean Sea, respectively.

In this work, the GRACE data and outputs of GLDAS model are integrated to estimate the groundwater storage changes ( $\Delta G W S$ ) in the Sinia Peninsula. Addressing this research for the arid environment of the Sinai area is important for studying the water resources development and for the development of replicable models that can be applied to similar areas worldwide.

\section{Geological and Hydrogeology of the Area}

Two groups of rock units (Figure 1) appear in the study area: (1) Precambrian crystalline rocks. These rocks are mainly composed of igneous and metamorphic rocks with fractures and fault zones. Many dykes of Tertiary age are cutting the basement rocks. They form the bulk of the southern mountains and represent part of the Arabian-Nubian Shield Massif [19-21]. (2) Thick Phanerozoic rocks. The Upper Jurassic-Lower Cretaceous fluviatile sandstone and conglomerates of the Malha Formation of the Nubian Sandstone Group overlay unconformably the basement rocks [21]. The Phanerozoic section is composed of Upper Cretaceous marine sandstone. Thick Tertiary Thebes Limestone overlies it [21]. Three potential aquifers are considered in Sinai. Quaternary aquifers are occupying $~ 50 \%$ of the area of the total aquifers in Sinai. They are located in the major wades and/or the deltas, composed of gravels and sands. The Lower Miocene sandstones of Gharandel Group [22] represent the Tertiary aquifers. The Cretaceous aquifers are formed of the lower and Middle Cretaceous units. The upper unit of Nubian Sandstone is considered to include the Lower Cretaceous sandstone, together with the overlying Cenomanian sandstone [21,23-25]. The Lower Cretaceous Nubian Sandstone represents the main water-bearing Formation in the area with a maximum $\sim 500 \mathrm{~m}$ thick; in central Sinai, it has a thickness varying from 70 to $130 \mathrm{~m}$ [26]. The Nubian aquifer in Sinai occupies a vast area extending from the crystalline rocks of central Sinai westward to the Gulf of Suez and northeastward to the Dead Sea [27].

\section{Data and Analysis Methods}

\section{Gravity data}

Two types of GRACE datasets were utilized in this research: the GRACE mascon and monthly solu- tions. The mascon solutions are provided by the University of Texas-Center for Space Research (UTCSR-M: http://www2.csr.utexas.edu/grace/). Mass concentration blocks (mascons) are another form of gravity field basis functions to which GRACE's inter-satellite ranging observations are fit. With mascons, geophysical constraints can be easily implemented. The CSR mascon products (Release: 06; v: 01 ; Spatial resolution: $0.25^{\circ} \times 0.25^{\circ}$ grid) use a defined grid newer than the RL05 version $[28,29]$. The mascon products have become widely used, given that all the observed signals are captured within the GRACE noise levels with the advantages of higher spatial resolution and minimum error. De-striping, smoothing filtering, and scaling techniques are not required with these mascon solutions [16,28,30-32]. The hexagonal tiles, spanning the coastline, are evenly divided into two tiles.

The monthly GRACE grids are used in the current study to analyze TWS variations. These products are processed from the Release- 05 spherical harmonics (https://grace.jpl.nasa.gov/data/get-data/monthly-mass-grids-land/). Some data centers are working on the spherical harmonics data and providing gravity solutions. Among these centers are: The (UT-CSR), NASA's Jet Propulsion Laboratory (NASA-JPL), and Deutsches GeoForschungsZentrum (GFZ). The TWS estimates from these solutions show a good correlation with each other, and a small difference among them is within the error margin [33].

The scale factor, corresponding to the gridded solutions, was applied to restore the amplitude-damping from the filtering process [34]. The solutions were scaled and averaged for the TWS calculations. The secular trends and the associated errors in $\triangle T W S$ were calculated.

\section{GLDAS}

Monthly GLDAS data [6] were utilized to estimate the components of the water storage. Two GLDAS versions are used: VIC [35], and CLM $[36,37]$. GLDAS is a land surface model that is integrating satellite and ground-based observational data products, using advanced land surface modeling and data assimilation techniques, to produce optimal simulated components for climatic investigations [6].

The high-quality, global land surface fields of GLDAS are used for climatic studies, water resources, and water cycle studies. The project has provided 


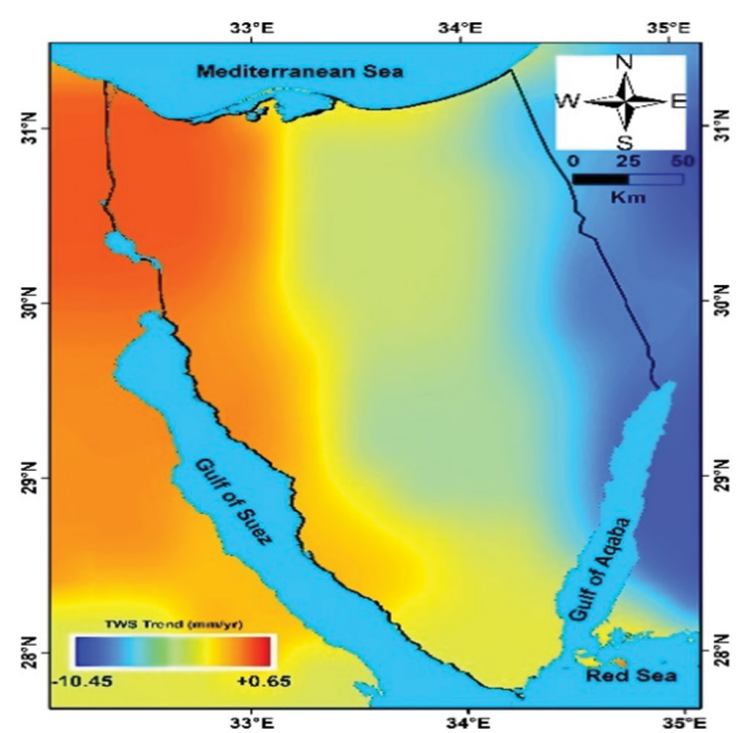

A

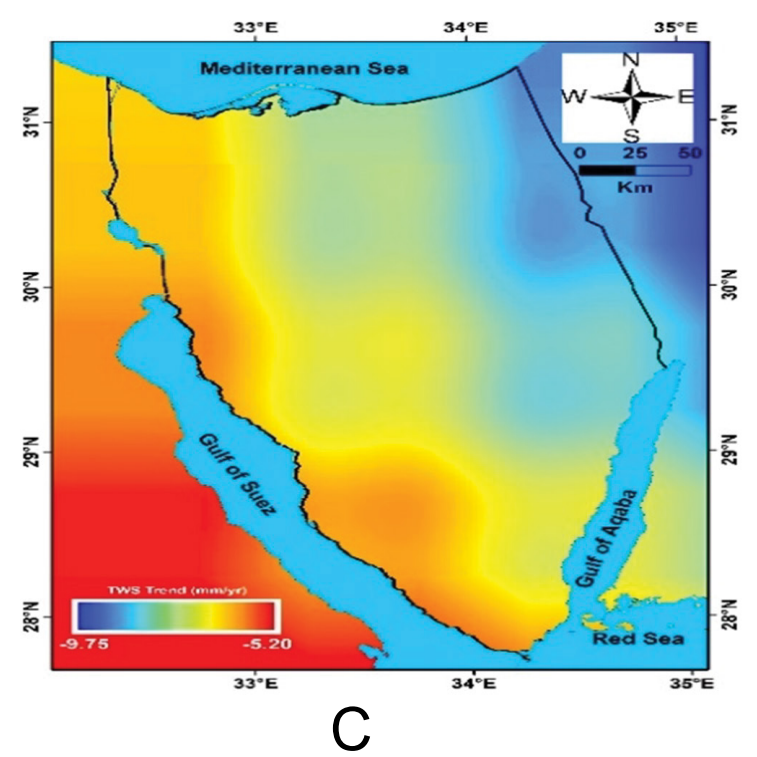

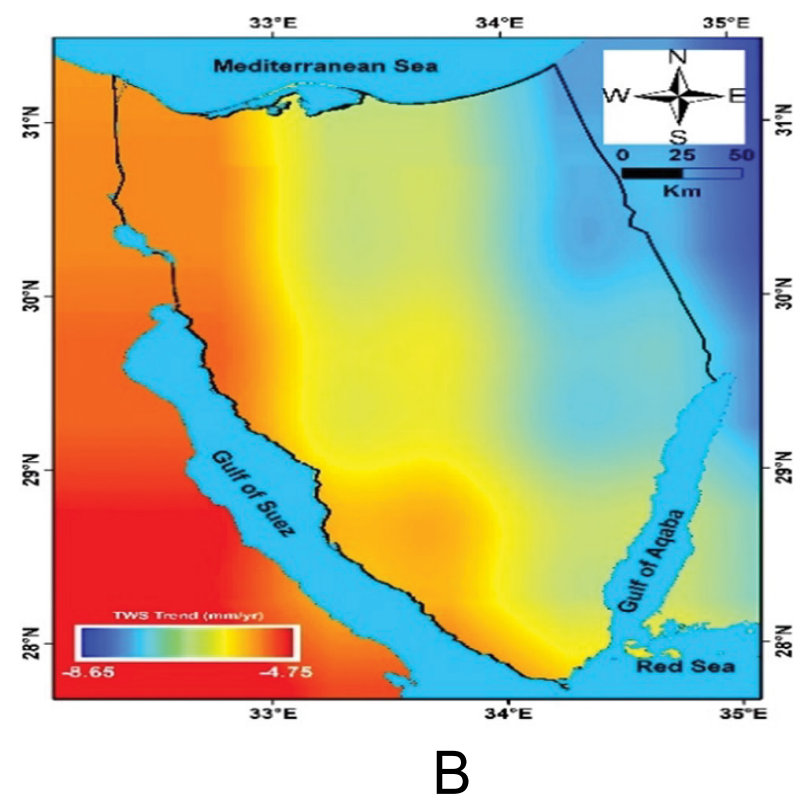

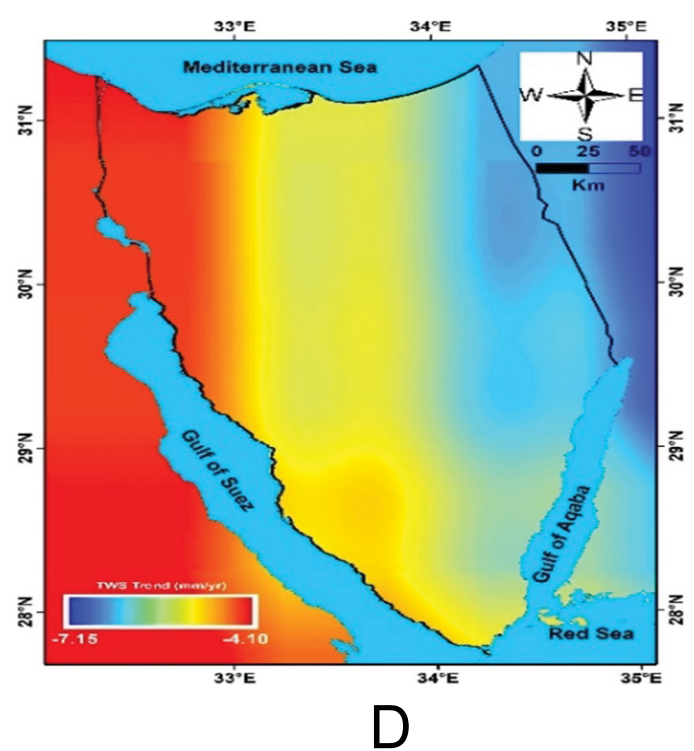

D

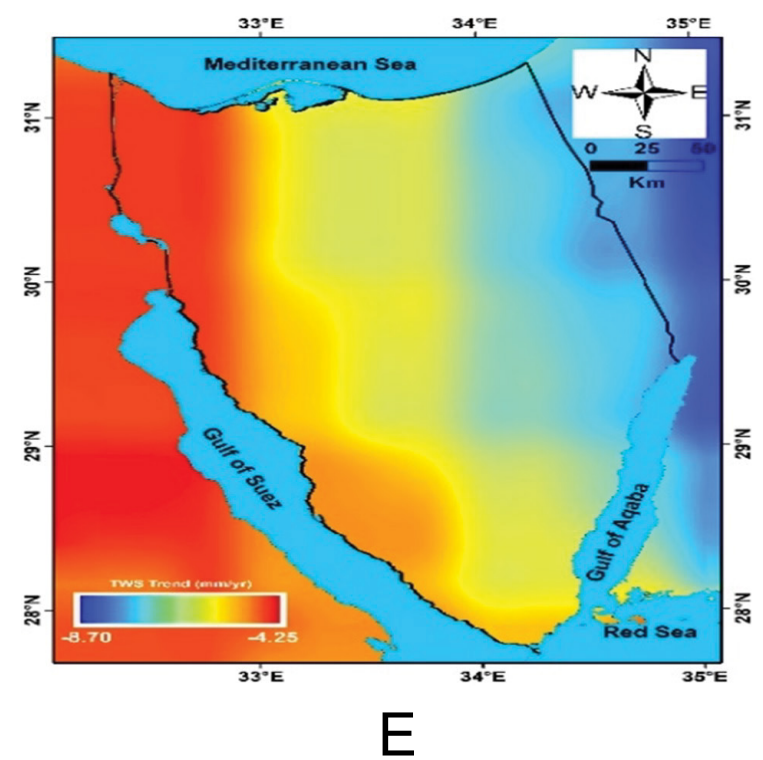

Figure 2: $\Delta$ TWS trend map of monthly (04/2002-07/2016) TWS solutions extracted from CSR-M (a), CSR-Mon (b), JPL-Mon (c), GFZ-Mon (d), and the average (e). 
a big archive of modeled and observed meteorological data, and output covering the Earth with $1^{\circ}$ and $0.25^{\circ}$ resolution spanning the period of 1948 to present. It includes four versions of the CLM, VIC, Mosaic and Noah [6,38-40].

GLDAS is generating optimal simulations of land surface states [6]. The GLDAS-derived soil moisture storage ( $\triangle \mathrm{SMS}$ ) variations were calculated by averaging the soil moisture estimates over the Sinai area. The $\triangle$ SMS variations represent the non-groundwater component of the TWS, given that the absence of the snow water equivalent and the canopy water storage variations over that area. Therefore, the $\triangle \mathrm{SMS}$ was only removed from the $\Delta$ TWS to estimate $\Delta G W S$. Ahmed, et al. [41] have shown that GLDAS is providing better estimates of soil moisture in arid/semiarid settings when compared to estimates from other land surface models over Saharan Africa.

\section{Rainfall data}

TRMM [42] monitors tropical and subtropical rainfall for weather forecasting, drought monitoring, and climate research (spatial domain: $50^{\circ} \mathrm{N}$ to $50^{\circ} \mathrm{S}$; spatial resolution: $0.25^{\circ}$; temporal resolution: 3-hours). Given the unavailability of the gauge stations over the Sinai, TRMM data were utilized in this study. The monthly and the AAP time series were created from the rainfall data. TRMM data were used to investigate the role of the rainfall on the groundwater behavior in the study area.

\section{Results and Discussion}

\section{Temporal variations in $\Delta$ TWS}

$\Delta T W S$ is the difference between the current and previous months' TWS. The spatial distribution of the secular trends in $\triangle$ TWS over the Sinai area is shown in Figure 2. Inspection of Figure 2 shows that the study area is witnessing significant negative TWS trends. The value of the average TWS trend decreases from a low negative value of $-4.25 \mathrm{~mm} /$ $\mathrm{yr}$ at the western parts to a high negative value of $-8.70 \mathrm{~mm} / \mathrm{yr}$ at the northeastern parts of the study area (Figure 2e). This indicates that the depletion

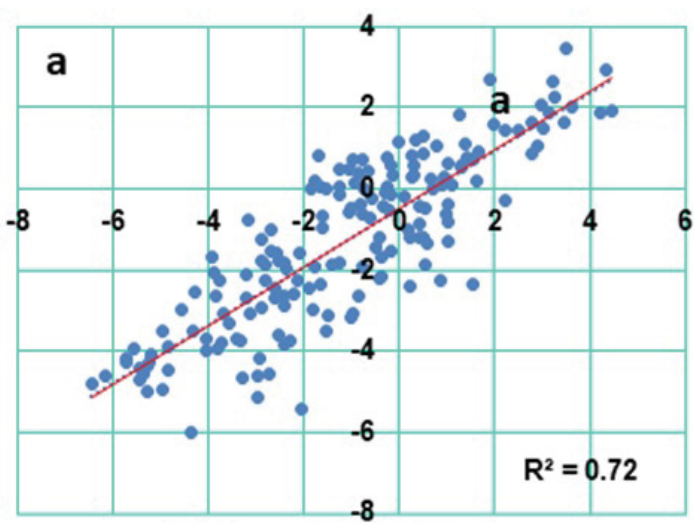

CSR-M \& AVG-Mon

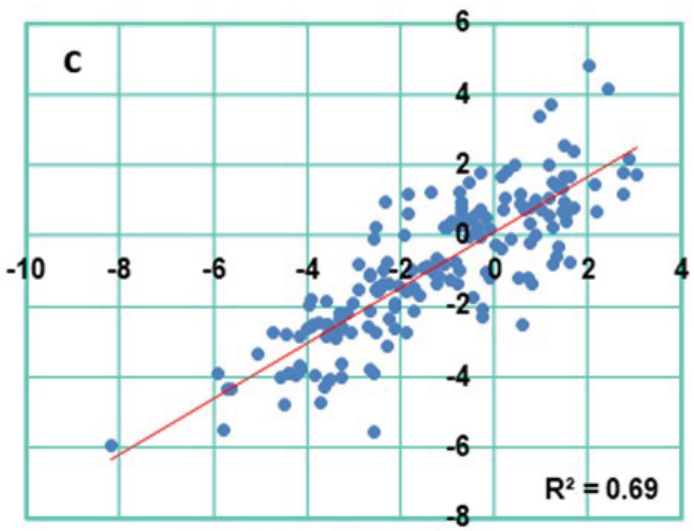

CSR-Mon \& GFZ-Mon

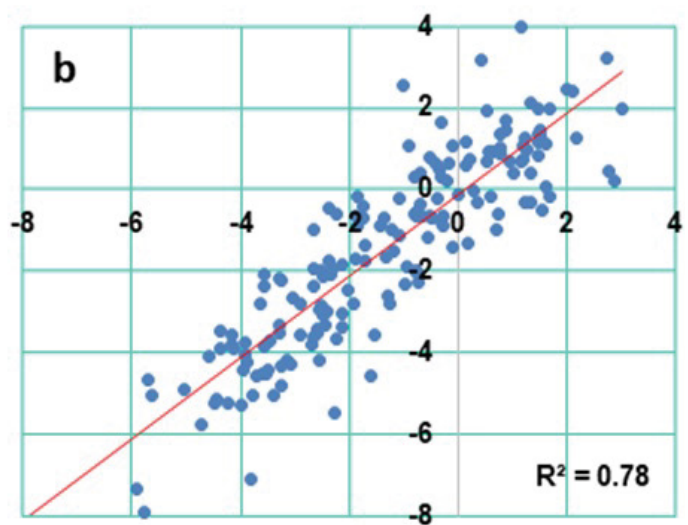

CSR-Mon \& JPL-Mon

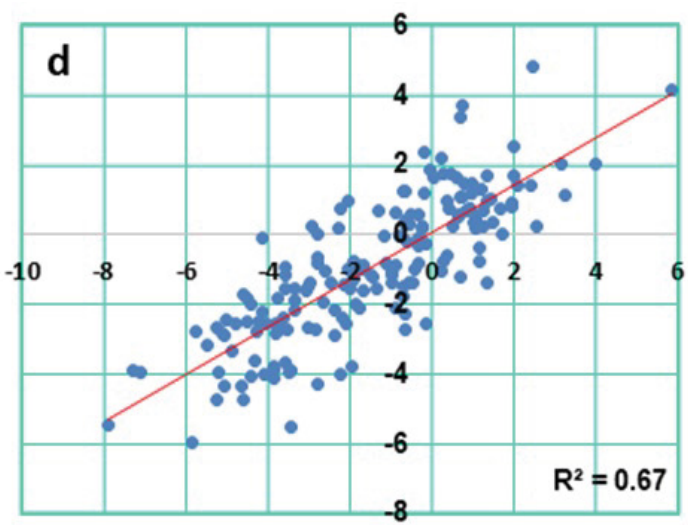

JPL-Mon \& GFZ-Mon

Figure 3: Correlation coefficients between $\triangle T$ TWS data from CSR-M, and average monthly GRACE solutions a) CSR-Mon, and JPL-Mon GRACE solutions; b) CSR-Mon, and GFZ-Mon GRACE solutions; c) and JPL-Mon and GFZMon GRACE solutions over Sinai during the investigated period. 
Table 1: GRACE solutions over the Sinai area.

\begin{tabular}{|c|c|c|c|}
\hline \multicolumn{2}{|c|}{ Variable } & $\begin{array}{l}\text { Trend } \\
(\mathrm{mm} / \mathrm{yr})\end{array}$ & \multirow{2}{*}{$\begin{array}{l}\begin{array}{l}\text { Volume } \\
\left(\mathrm{km}^{3} / \mathrm{yr}\right)\end{array} \\
-0.224 \pm 0.0214\end{array}$} \\
\hline \multirow{5}{*}{ 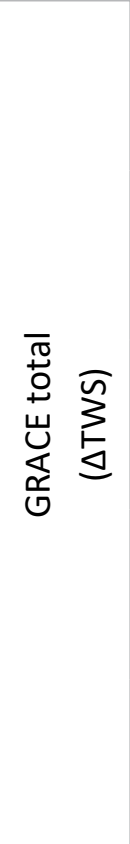 } & $\begin{array}{l}\text { CSR-M } \\
\text { P value }\end{array}$ & $\begin{array}{l}-3.68 \pm 0.35 \\
<0.0001\end{array}$ & \\
\hline & $\begin{array}{l}\text { CSR-MON } \\
\text { P value }\end{array}$ & $\begin{array}{l}-4.06 \pm 0.24 \\
<0.0001\end{array}$ & $-0.247 \pm 0.015$ \\
\hline & $\begin{array}{l}\text { JPL-MON } \\
\text { P value }\end{array}$ & $\begin{array}{l}-4.64 \pm 0.27 \\
<0.0001\end{array}$ & $-0.28 \pm 0.017$ \\
\hline & $\begin{array}{l}\text { GFZ-MON } \\
\text { P value }\end{array}$ & $\begin{array}{l}-3.30 \pm 0.27 \\
<0.0001\end{array}$ & $-0.20 \pm 0.017$ \\
\hline & $\begin{array}{l}\text { AVG } \\
\text { P value }\end{array}$ & $\begin{array}{l}-3.92 \pm 0.23 \\
<0.0001\end{array}$ & $-0.238 \pm 0.014$ \\
\hline $\begin{array}{l}\Delta S M S \\
P \text { value }\end{array}$ & & $\begin{array}{l}-1.35 \pm 0.03 \\
<0.0001\end{array}$ & $-0.082 \pm 0.002$ \\
\hline \multirow{5}{*}{ 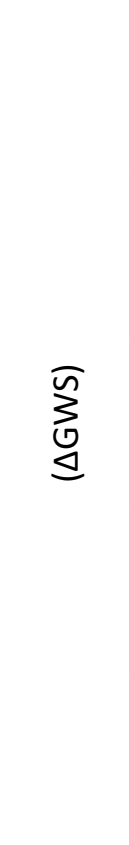 } & $\begin{array}{l}\text { CSR-M } \\
\text { P value }\end{array}$ & $\begin{array}{l}-2.33 \pm 0.34 \\
<0.0001\end{array}$ & $-0.142 \pm 0.02$ \\
\hline & $\begin{array}{l}\text { CSR-Mon } \\
\text { P value }\end{array}$ & $\begin{array}{l}-2.71 \pm 0.24 \\
<0.0001\end{array}$ & $-0.165 \pm 0.015$ \\
\hline & $\begin{array}{l}\text { JPL- Mon } \\
\text { P value }\end{array}$ & $\begin{array}{l}-3.29 \pm 0.27 \\
<0.0001\end{array}$ & $-0.199 \pm 0.016$ \\
\hline & $\begin{array}{l}\text { GFZ- Mon } \\
\text { P value }\end{array}$ & $\begin{array}{l}-1.95 \pm 0.27 \\
<0.0001\end{array}$ & $-0.119 \pm 0.016$ \\
\hline & AVG & $\begin{array}{l}-2.57 \pm 0.22 \\
<0.0001\end{array}$ & $-0.16 \pm 0.013$ \\
\hline AAP & & 44.91 & 2.73 \\
\hline
\end{tabular}

rate is increasing from the west toward the east and northeast. Good correlation coefficients of 0.67-0.78 are obtained among the different GRACE solutions over the study area (Figure 3). The scaled GRACE-derived TWS time series (Figure 4) are experiencing negative TWS trends. The study area has an average TWS trend value of $-3.92 \pm 0.23 \mathrm{~mm} / \mathrm{yr}$ (Table 1).

\section{Depletion rate}

As mentioned above, the GRACE TWS has no vertical resolution, so the simulated TWS components of GLDAS models were integrated to subtract the non-groundwater partitions from TWS. Equation (1) is used to partition the TWS into its components over the investigated area.

$$
\Delta \mathrm{TWS}=\Delta \mathrm{GWS}+\Delta \mathrm{SMS}
$$

The average $\triangle \mathrm{SMS}$ value of the two GLDAS versions (VIC and CLM) was estimated. The temporal change in GLDAS-derived SMS and the secular trend over the study area is shown in Figure 5. The average GLDAS-derived $\triangle$ SMS time series is witnessing a negative trend, estimated at $-1.35 \pm 0.032 \mathrm{~mm} /$ yr. By applying Equation 1, $\Delta G W S$ was estimated over the investigated area.

Figure 6 shows the $\Delta$ GWS time series generated based on Equation (1) over the study area. Witnessing of Figure 6 shows that the Sinai area is experiencing a general $\Delta G W S$ decline of $-2.57 \pm 0.22$ $\mathrm{mm} / \mathrm{yr}\left(-0.16 \pm 0.013 \mathrm{~km}^{3} / \mathrm{yr}\right)$. Although the general trend in the groundwater storage variations is witnessing a depletion, minor modern recharge rate is believed to occur through the sandstone outcrops at the northern flanks of the crystalline rocks in central Sinai [43]. Previous studies have shown that the Nubian aquifer was recharged when more humid climatic conditions were prevailed in the Quaternary time by the intensification of paleomonsoons $[44,45]$ or intensification of paleowesterlies $[46,47]$.

\section{Analysis of precipitation data}

The analysis of TRMM data over the Sinai area shows that the monthly rainfall values are characterized by higher rates during October-March months, and with lower rates in May-August months (Figure 7). These rates indicate that the Sinai area is receiving lower rainfall rates in that semiarid environment. Inspection of Figure 8 shows that the rainfall is very low over most parts of Sinai, whereas it shows little substantial rates close to the Gulf of Aqaba, Suez Canal, and the northeastern parts. The AAP time series (Figure 9) shows a decrease from $68.5 \mathrm{~mm}$ in 2002 to $22.3 \mathrm{~mm}$ in 2009, and then an increase to $50.3 \mathrm{~mm}$ in 2016, with an average of $44.91 \mathrm{~mm} / \mathrm{yr}\left(2.73 \mathrm{~km}^{3} / \mathrm{yr}\right)$ during the studied period. The rainfall contribution to the groundwater recharge seems to be very low, given the low precipitation rates, and the surface runoff toward the Gulf 


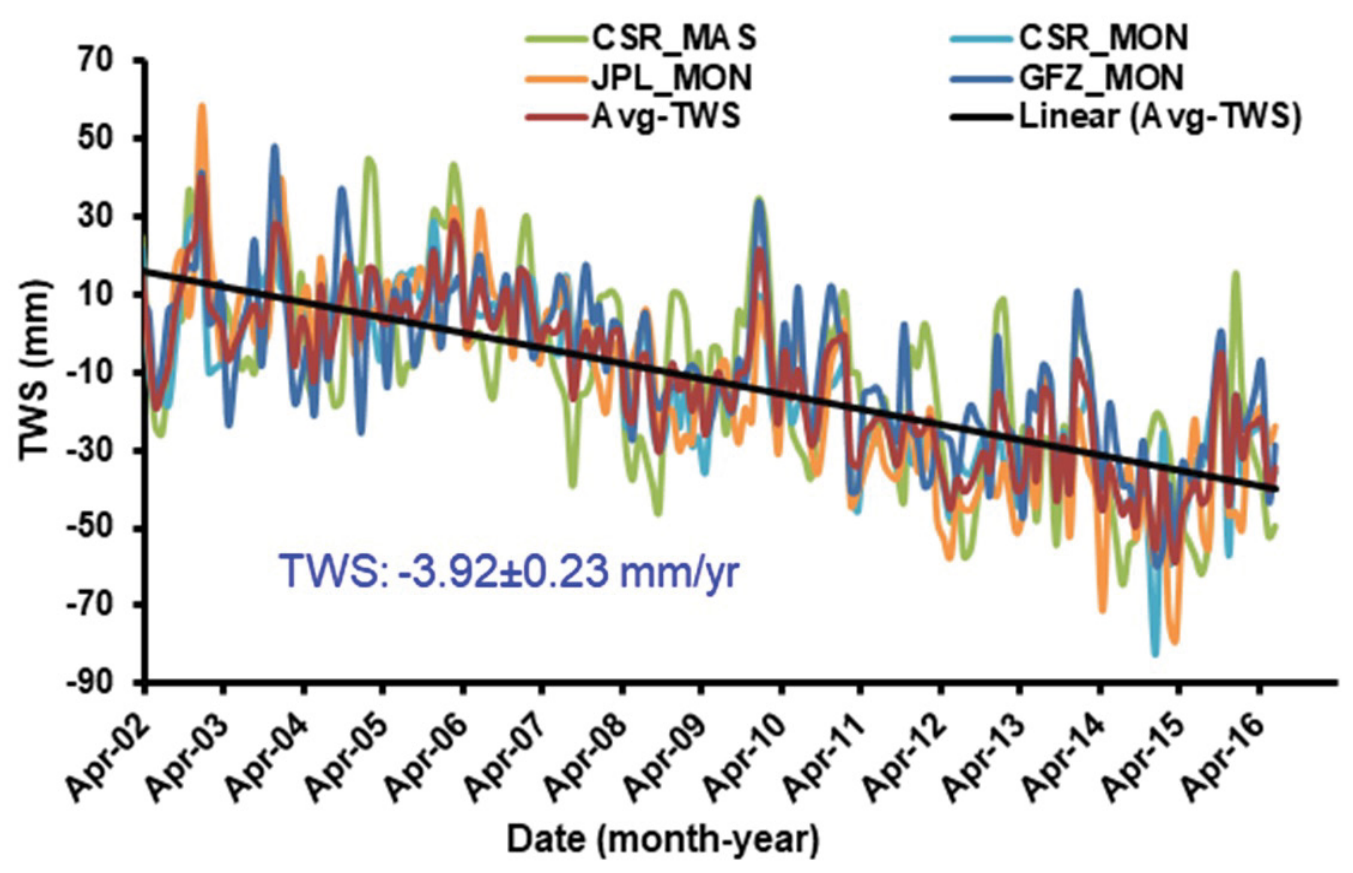

Figure 4: GRACE-derived $\triangle T W S$ and their averaging over Sinai area.

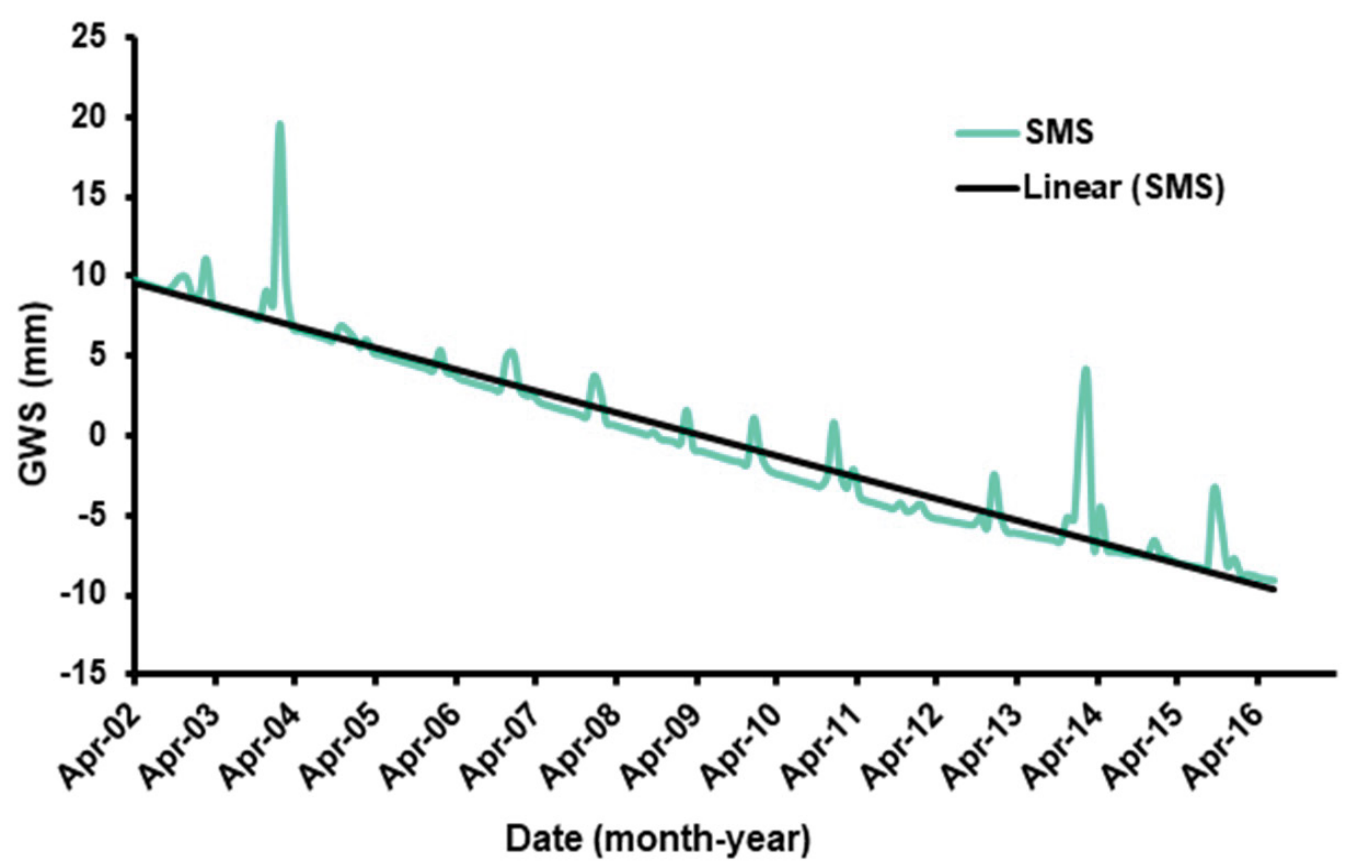

Figure 5: GLDAS-derived $\triangle S M S$ over Sinai area.

of Aqaba, Gulf of Suez, and the Mediterranean Sea as it is shown from the drainage basins and stream networks over the area (Figure 10). Therefore, the rainfall might have low effects on the recharging of the groundwater aquifers in the study area.

\section{Structural effects on groundwater behavior}

The groundwater elevation data is showing in Figure 1. It shows that the groundwater in the aquifers in Sinai and the Negev area flows towards the discharge areas of the aquifers $[43,48]$. The Gulf of Suez, the Dead Sea, and the Gulf of Aqaba represent the most important natural outlets of the aquifers. The south to north groundwater flow seems to be partially impeded by the E-W trending Themed and Minsharah shear zones (Figure 1). To the north, the groundwater flows subparallel to the NE-trending folds and faults of the Syrian Arc System. The flow system is provided from the groundwater elevation data (Sinai, Wadi Sheira: +467 mamsl; El Themed: 


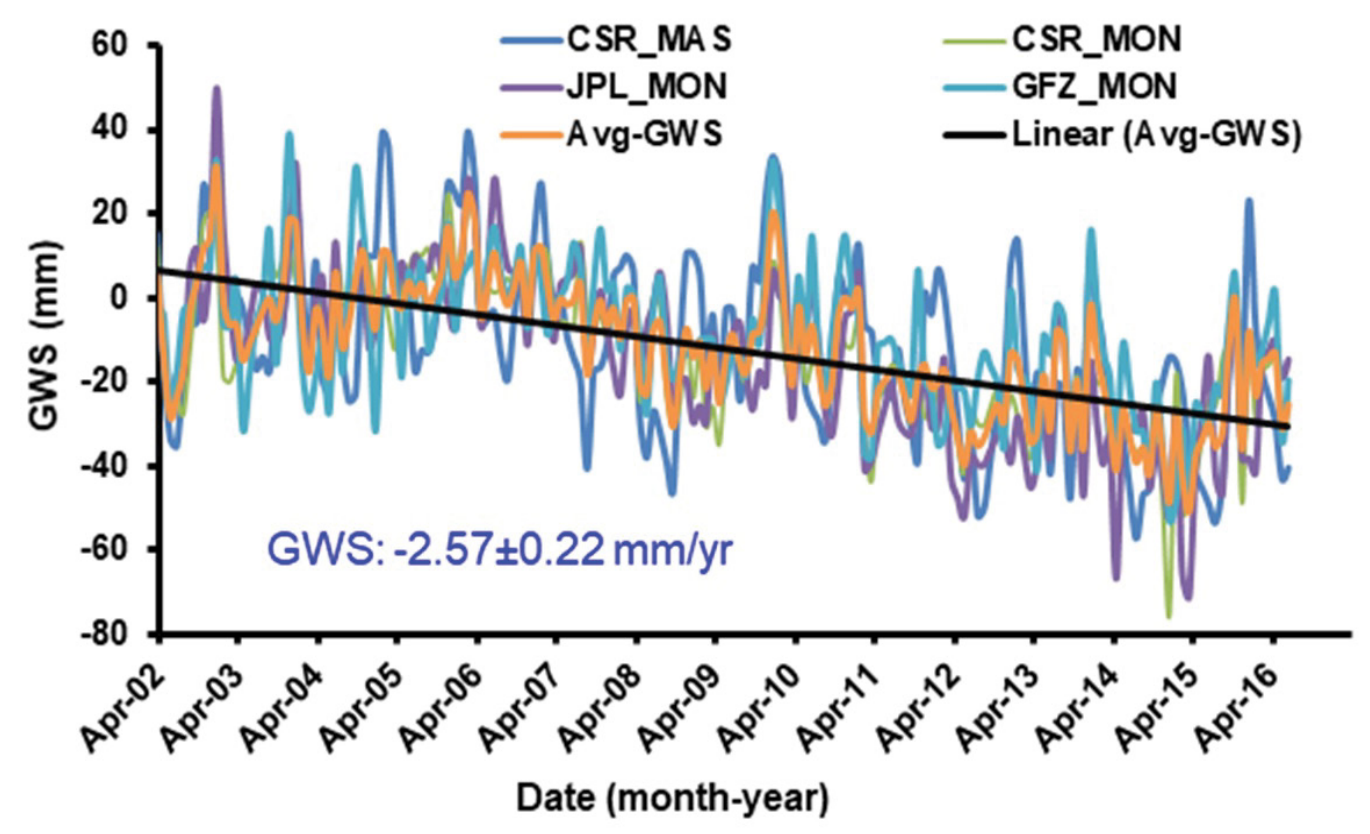

Figure 6: GRACE-derived $\triangle$ GWS and their averaging over Sinai area.

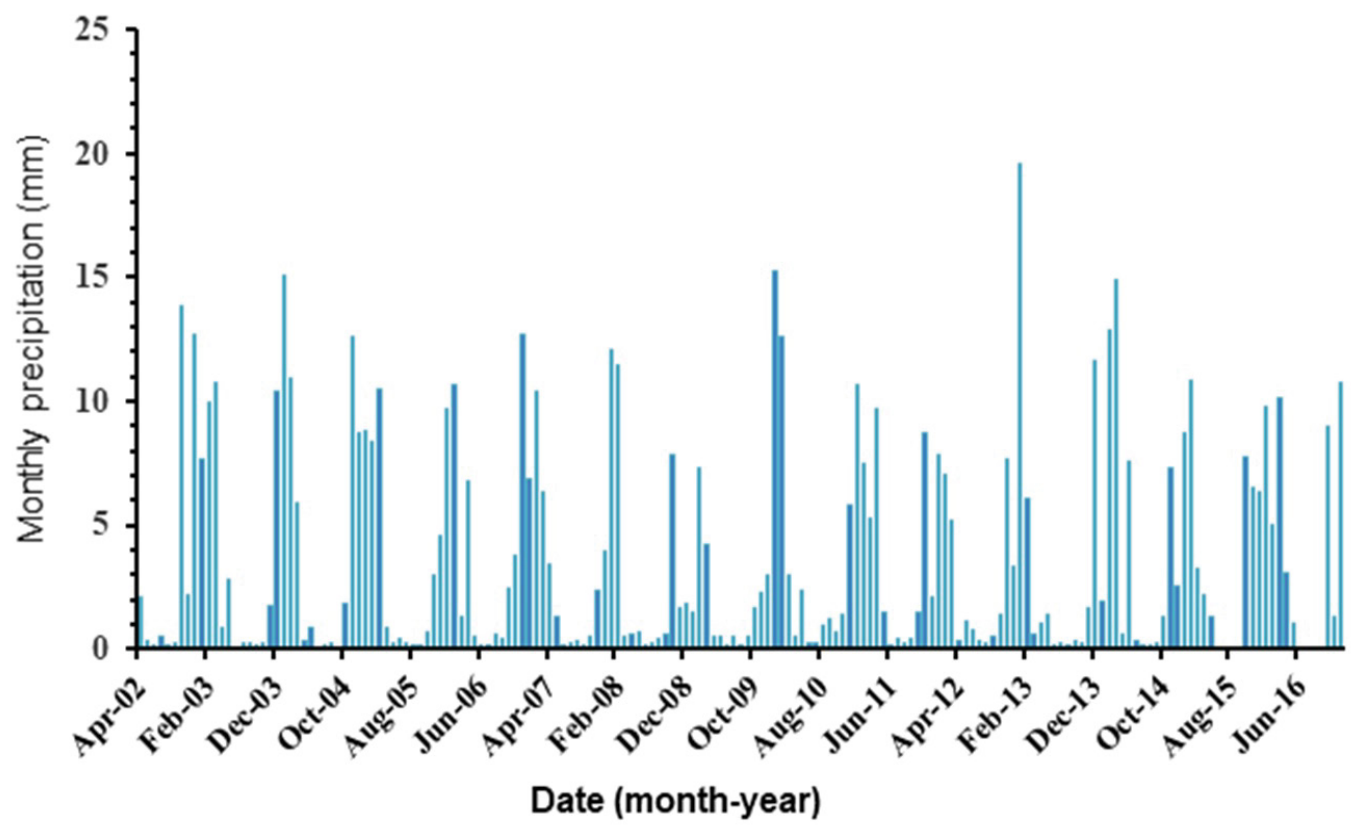

Figure 7: Precipitation over Sinai during the investigated period.

+248 mamsl; Shizafon in the eastern Negev: +185 mamsl; and Well Qetura 5 in the Arava Valley: +50 mamsl (Rosenthal, et al. [49]; Figure 1). On the general scale, the inspection of the $\Delta$ TWS shows that the direction of the groundwater flow is from the west and southwest toward the east and northeast. This is provided from the distribution of the $\Delta$ TWS over Sinai. Given that, the shear zones in central and north Sinai represent areas of concentrated brittle deformation. One would expect enhanced porosity, and permeability proximal to the faults of the shear zones compared to the surroundings.
This helps the groundwater flow subparallel to the shear zones toward the natural outlets in the east and the west, and partially northward across these shear zones.

\section{Conclusion}

Based on the GRACE and GLDAS datasets, the groundwater resources of the Sinai area are studied during the period of 04/2002-07/2016. The Sinai area is located in an arid/semi-arid zone. It is receiving average annual precipitation of $44.91 \mathrm{~mm} /$ $\mathrm{yr}\left(2.73 \mathrm{~km}^{3} / \mathrm{yr}\right)$ during the investigated period. 


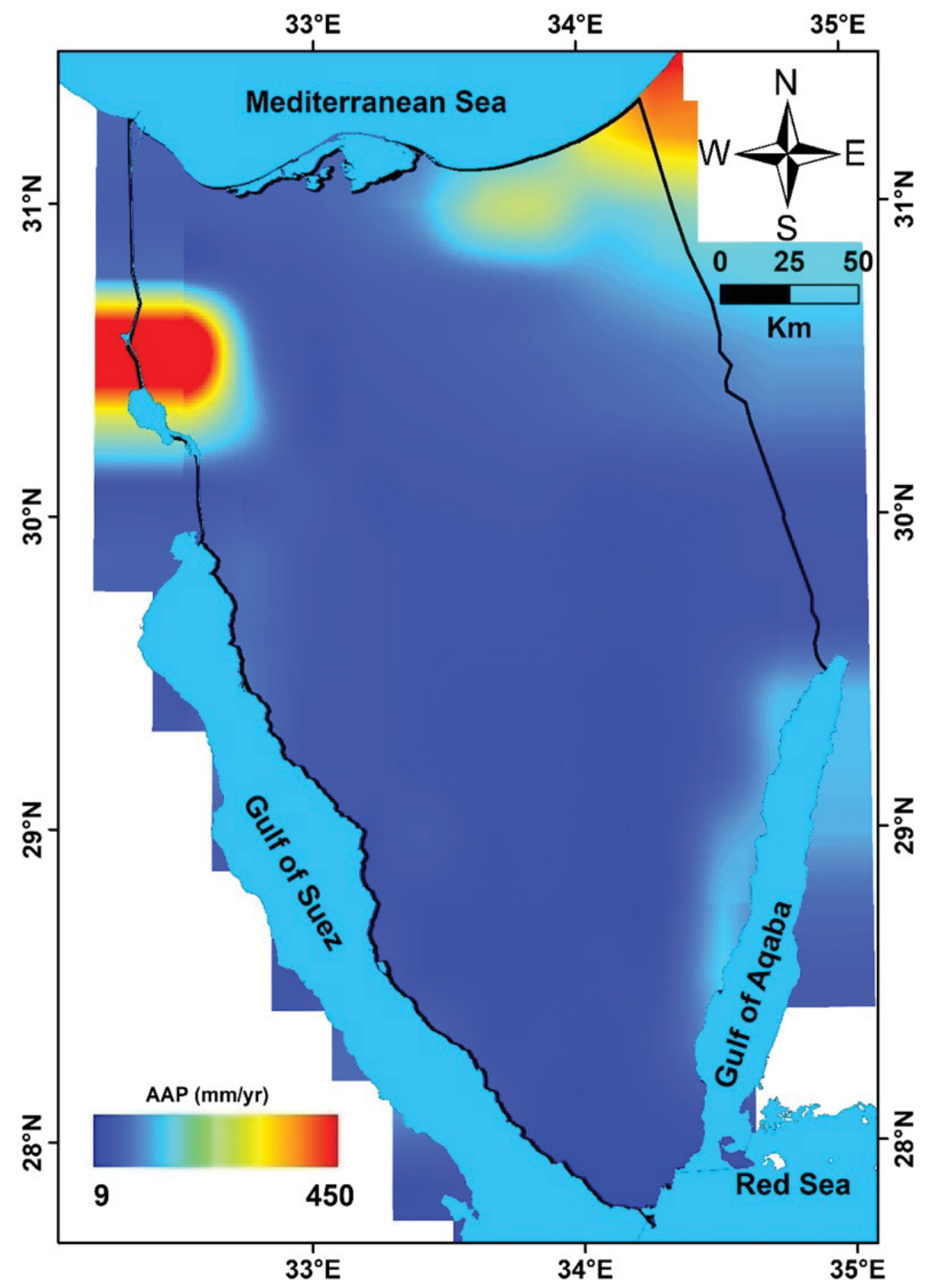

Figure 8: TRMM-derived AAP for the period (04/2002-07/2016) over Sinai area.

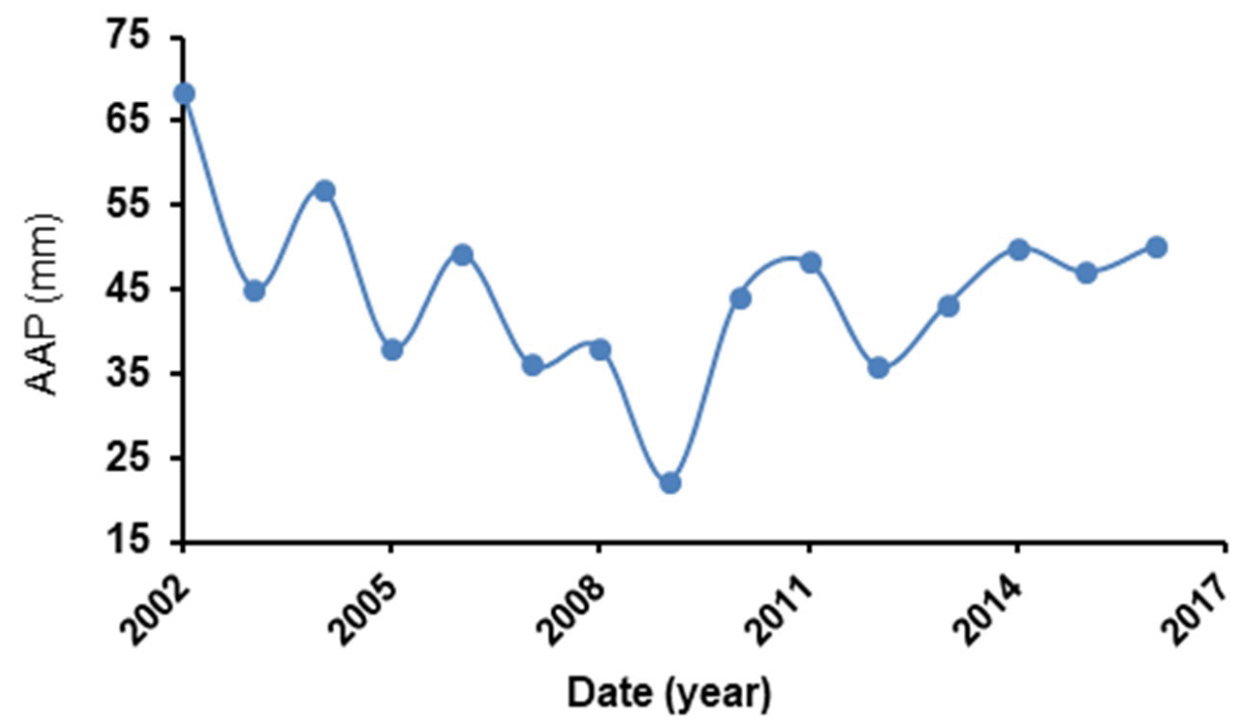

Figure 9: The AAP over Sinai area. 


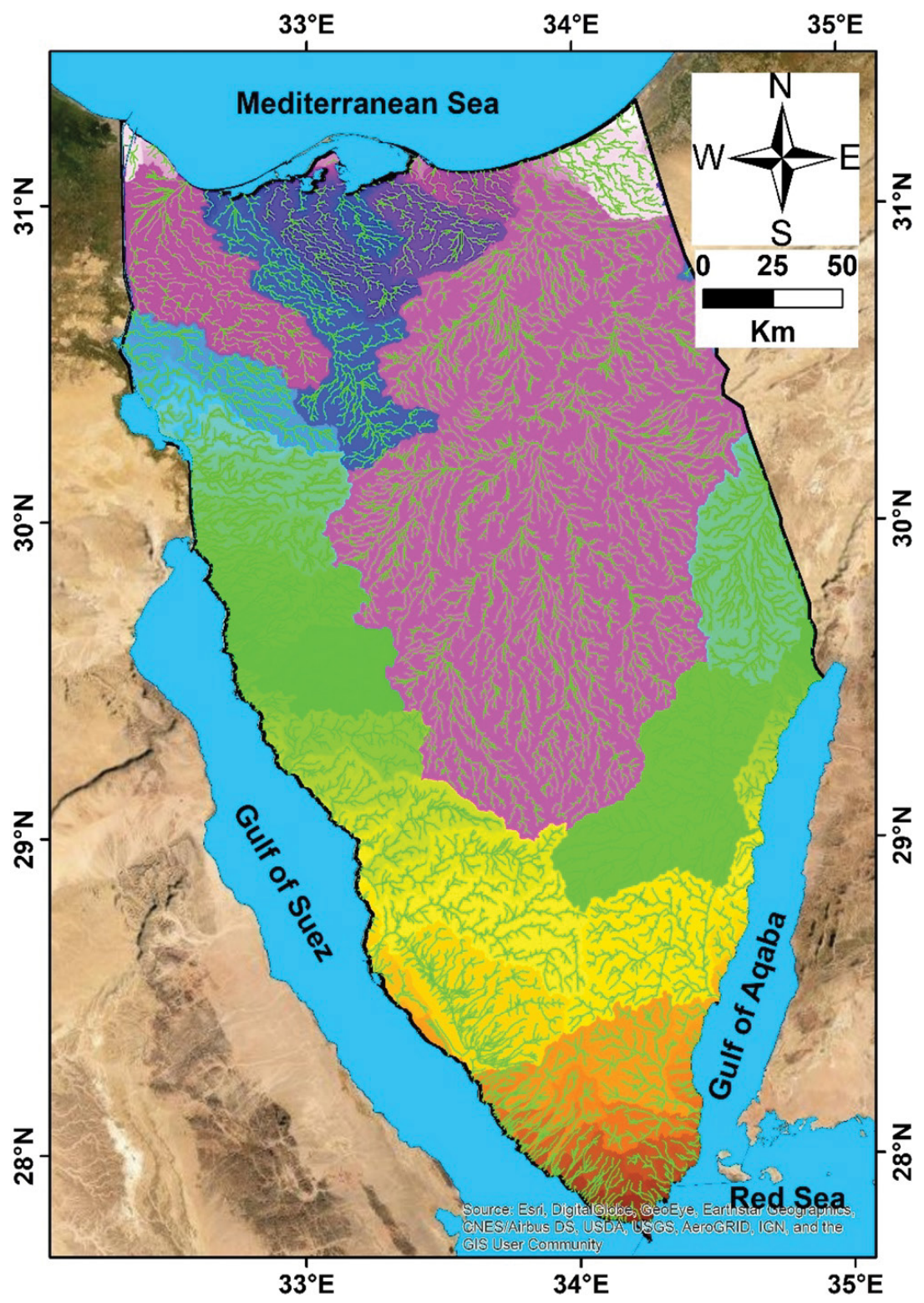

Figure 10: The basins of the Sinai and the stream networks extracted from Shuttle Radar Topography Mission $90 \mathrm{~m}$.

The GRACE-derived $\triangle T$ TWS is witnessing a general depletion trend, increasing toward the east and northeast. The study area is witnessing a groundwater depletion during that period. The GRACE-derived $\triangle G W S$ rate was calculated at $-2.57 \pm 0.22$ $\mathrm{mm} / \mathrm{yr}\left(-0.16 \pm 0.013 \mathrm{~km}^{3} / \mathrm{yr}\right)$. Minor recharge may occur over the sandstone outcrops at the foothills of the mountains of central Sinai and the fractured basement zones. The Dead Sea, Gulf of Suez, Gulf of Aqaba, and the Mediterranean Sea represent the natural outlets of the groundwater and surface water of the study area. Some dams should be constructed across the main streams to preserve the water for human needs and recharging the deep groundwater aquifers.

\section{Acknowledgments}

The author would like to thank the editor and the anonymous reviewers of the IJESG for their valuable comments.

\section{References}

1. Famiglietti JS (2004) Remote sensing of terrestrial water storage, soil moisture and surface waters. In: Sparks RSJ, Hawkesworth CJ, The state of the planet: Frontiers and challenges in geophysics. American Geophysical Union, Washington, DC, 197-207.

2. Lettenmaier DP, Famiglietti JS (2006) Water from on high. Nature 444: 562-563.

3. Syed TH, Famiglietti JS, Rodell M, Chen JL, Wilson CR (2008) Analysis of terrestrial water storage changes 
from GRACE and GLDAS. Water Resour Res 44.

4. Andersen OB, Hinderer J (2005) Global inter-annual gravity changes from GRACE: Early results. Geophysical Research Letters 32.

5. Phillips T, Nerem RS, Fox-Kemper B, Famiglietti JS, Rajagopalan B (2012) The influence of ENSO on global terrestrial water storage using GRACE. Geophys Res Lett 39.

6. Rodell M, Famiglietti JS, Chen J, Seneviratne SI, Viterbo $P$, et al. (2004) Basin scale estimates of evapotranspiration using GRACE and other observations. Geophysical Research Letters 31: L20504.

7. Syed TH, Famiglietti JS, Chen J, Rodell M, Seneviratne SI, et al. (2005) Total basin discharge for the Amazon and Mississippi River basins from GRACE and a land-atmosphere water balance. Geophysical Research Letters 32: L24404.

8. Ahmed M, Sultan M, Wahr J, Yan E, Milewski A, et al. (2011) Integration of GRACE (Gravity Recovery and Climate Experiment) data with traditional data sets for a better understanding of the time-dependent water partitioning in African watersheds. Geology 39: 479-482.

9. Ferreira VG, Gong Z, Andam-Akorful SA (2012) Monitoring mass changes in the Volta river basin using GRACE satellite gravity and TRMM precipitation. Boletim de Ciencias Geodesicas 18: 549-563.

10.Ahmed M, Sultan M, Wahr J, Yan E (2014) The use of GRACE data to monitor natural and anthropogenic induced variations in water availability across Africa. Earth-Science Reviews 136: 289-300.

11. Mohamed A, Sultan M, Ahmed M, Yan E (2014) Quantifying modern recharge to the Nubian Sandstone Aquifer System: Inferences from GRACE and Land Surface Models. American Geophysical Union, Fall Meeting.

12. Mohamed A, Sultan M, Yan E, Ahmed M, Sturchio N, et al. (2015) Towards a better understanding of the hydrologic setting of the Nubian Sandstone Aquifer System: Inferences from groundwater flow models, $\mathrm{Cl}-36$ ages, and GRACE data. American Geophysical Union, Fall Meeting.

13. Mohamed A, Sultan M, Ahmed M, Yan E, Ahmed E (2017) Aquifer recharge, depletion, and connectivity: Inferences from GRACE, land surface models, and geochemical and geophysical data. GSA Bulletin 129: 534-546.

14.Mohamed A (2019) Hydro-geophysical study of the groundwater storage variations over the Libyan area and its connection to the Dakhla basin in Egypt. Journal of African Earth Sciences 157: 103508.
15. Mohamed A (2020) Gravity based estimates of modern recharge of the Sudanese area. Journal of African Earth Sciences 163: 103740.

16. Mohamed A (2020) Gravity applications in estimating the mass variations in the Middle East: $A$ case study from Iran. Arab J Geosci 13.

17. Mohamed A (2020) Gravity applications to groundwater storage variations of the Nile Delta Aquifer. Journal of Applied Geophysics 182: 104177.

18. Mohamed A, Gonçalvès J (2020) Quantifying groundwater resources and recharge rates of the North-Western Sahara Aquifers system using satellite gravity data.

19. Sultan M, Arvidson RE, Duncan IJ, Stern RJ, El Kaliouby $B$ (1988) Extension of the Najd shear system from Saudi Arabia to the central Eastern Desert of Egypt based on integrated field and Landsat observations. Tectonics 7: 1291-1306.

20.Stern RJ, Kroner A (1993) Late Precambrian crustal evolution in NE Sudan: Isotopic and geochronologic constraints. Journal of Geology 101: 555-574.

21.Sultan M, Metwally S, Milewski A, Becker D, Ahmed $M$, et al. (2011) Modern recharge to fossil aquifers: Geochemical, geophysical, and modeling constraints. Journal of Hydrology 403: 14-24.

22.Shata A (1992) Watershed management, development of potential water resources and desertification control in Sinai. Proceedings of the $3^{\text {rd }}$ Conference on the Geology and Development of Sinai, Ismailia, Egypt, Dec. 2007, 273-280.

23.El Kashouty M, ELSayed MH, El Godamy Y, Gad M, Mansour M (2012) Characterization of the aquifer system in the northern Sinai Peninsula, Egypt. Journal of Environmental Chemistry and Ecotoxicology 4: 41-63.

24.Dames, Moore (1982) Agricultural and water investigation of sinai, Phase 1. Ministry of Development and New Communities, A.R.E., Cairo, Egypt.

25.Al-Gamal SA, Sadek M (2015) An assessment of water resources in Sinai Peninsula, using conventional and isotopic techniques, Egypt'. Int J Hydrology Science and Technology 5: 241-257.

26. Kora M (1995) An introduction to the stratigraphy of Egypt. Lecture Notes, Geology Department, Michigan University, US, 110.

27.El Tahlawi MR (2014) Sinai Peninsula: An overview of geology and thermal groundwater potentialities. In: Balderer W, Porowski A, Idris H, LaMoreaux J, Thermal and Mineral Waters. Environmental Earth Sciences, Springer, Berlin, Heidelberg. 
28.Save H, Bettadpur S, Tapley B (2016) High resolution CSR GRACE RL05 mascons. JGR Solid Earth 121: 7547-7569.

29.https://dataverse.tdl.org/dataset.xhtml?persistentld=doi:10.18738/T8/UN91VR

30.Watkins MM, Wiese DN, Yuan D, Boening C, Landerer FW (2015) Improved methods for observing Earth's time variable mass distribution with GRACE using spherical cap mascons. J Geophys Res Solid Earth 120: 2648-2671.

31.Scanlon BR, Zhang Z, Save H, Wiese DN, Landerer FW, et al. (2016) Global evaluation of new GRACE mascon products for hydrologic applications. Water Resour Res 52: 9412-9429.

32.Ahmed M, Abdelmohsen K (2018) Quantifying modern recharge and depletion rates of the Nubian aquifer in Egypt. Surv Geophys 39: 729-751.

33.Sakumura C, Bettadpur S, Bruinsma S (2014) Ensemble prediction and intercomparison analysis of GRACE time-variable gravity field models. Geophys Res Lett 41: 1389-1397.

34.Landerer FW, Swenson SC (2012) Accuracy of scaled GRACE terrestrial water storage estimates. Water Resources Research 48.

35.Liang X, Lettenmaier DP, Wood EF (1996) One-dimensional statistical dynamic representation of subgrid spatial variability of precipitation in the two-layer variable infiltration capacity model. J Geophys Res 101: 21403-21422.

36.Bonan GB, Oleson KW, Vertenstein M, Levis S, Zeng $X B$, et al. (1998) The land surface climatology of the NCAR Land Surface Model coupled to the NCAR Community Climate Model. J Climate 11: 1307-1326.

37.Dai YJ, Zeng QC (1997) A land surface model (IAP94) for climate studies, Part I: Formulation and validation in off-line experiments. Adv Atmos Sci 14: 443-460.

38. Koster RD, Suarez MJ (1996) Energy and water balance calculations in the Mosaic LSM. Technical report series on global modeling and data assimilation, NASA technical memorandum, 104606, 9: 60.

39.Koren V, Schaake J, Mitchell K, Duan KY, Chen F, et al. (1999) A parameterization of snowpack and fro- zen ground intended for NCEP weather and climate models. J Geophys Res 104: 19569-19585.

40.Dai Y, Zeng X, Dickinson RE, Baker I, Bonan G, et al. (2003) The common land model. Bull Am Meteorol Soc 84: 1013-1023.

41.Ahmed M, Sultan M, Yan E, Wahr J (2016) Assessing and improving land surface model outputs over Africa using GRACE, field, and remote sensing data. Surv Geophys 37: 529-556.

42. Huffman GJ, Bolvin DT, Nelkin EJ, Wolff DB, Adler RF, et al. (2007) The TRMM Multisatellite Precipitation Analysis (TMPA): Quasi-global, multiyear, combined-sensor precipitation estimates at fine scales. Journal of Hydrometeorology 8: 38-55.

43. Isaar A, Bein A, Michaeli M (1972) On the ancient water of the Nubian sandstone aquifer in Central Sinai and Southern Israel. J Hydrol 17: 353-374.

44.Sarnthein M, Tetzlaff G, Koopman B, Wolter K, Pflaumann $U$ (1981) Glacial and interglacial wind regimes over the eastern subtropical Atlantic and NorthWest Africa. Nature 293: 193-196.

45. Yan ZW, Petit-Maire N (1994) The last $140 \mathrm{ka}$ in the Afro-Asian climatic transitional zone. Palaeogeog Palaeoclimatol Palaeoecology 110: 217-233.

46.Sultan M, Sturchio N, Hassan FA, Hamdan MAR, Mahmood AM, et al. (1997) Precipitation source inferred from stable isotopic composition of Pleistocene groundwater and carbonate deposits in the Western Desert of Egypt. Quaternary Research 48: 29-37.

47.Abouelmagd A, Sultan M, Sturchio NC, Soliman F, Rashed M, et al. (2014) Paleoclimate record in the Nubian Sandstone Aquifer, Sinai Peninsula, Egypt. Quaternary Research (United States) 81: 158-167.

48. Rosenthal E, Jones BF, Weinberger G (1998) The chemical evolution of Kurnub Group paleowater in the Sinai-Negev province - a mass balance approach. Appl Geochem 27: 1-17.

49. Rosenthal E, Zilberbrand M, Livshitz Y (2007) The hydrochemical evolution of brackish groundwater in central and northern Sinai (Egypt) and in the western Negev (Israel). Journal of Hydrology 337: 294-314. 